\title{
«Империальная формула» в русской поэзии
}

\author{
Е. В. ДУШЕЧКИНА \\ Кафедра истории русской литературы, Санкт-Петербургский государственный университет, \\ Университетская набережная, д. 11, RU-199034 Санкт-Петербург \\ E-mail: dushechkina@yandex.ru
}

(Received: 19 March 2015; accepted: 8 June 2015)

\begin{abstract}
L. Pumpyansky noted the frequent use of "Imperial formula" or "formula stretch of Russia" in 18th-century Russian poetry (mainly in Lomonosov's works). This poetic structure is built by using the prepositions from and to: from one boundary to the other ("From the White sea to the Black sea"). The size of the Russian territory has always been a source of pride for Russian national consciousness, satisfying national geopolitical ambitions and, apparently, thus the "Imperial formula" has often been used in Russian poetry for over three centuries.

Keywords: Russian poetry, "Imperial formula", territory, boundary, geopolitics
\end{abstract}

Л. В. Пумпянский в статье 1940 г. «Ломоносов и немецкая школа разума» обратил внимание на особую риторическую фигуру, которую часто использовал Ломоносов в своих стихотворных произведениях. Пумпянский назвал ее «формулой протяжения России» (сделав акцент на пространственном и географическом ее аспектах), или (используя политическую терминологию) «империальной формулой» (Пумпянский 1983: 22-23). Для того чтобы сразу было понятно, о какой языковой конструкции идет речь, приведем характерный пример применения «империальной формулы» в одной из од Ломоносова: «От теплых уж брегов Азийских / Вселенной часть до вод Балтийских / В объятьи вашем вся лежит» (Ломоносов 1965: 72). Об этой конструкции, которой суждено было сыграть заметную роль в русской политической и патриотической поэзии, а также в публицистической прозе, и пойдет речь в настоящей работе.

Прежде чем перейти к изложению литературной истории и интерпретации «империальной формулы», мы обратим внимание на ее грамматическое строение. Обычно она оформляется двумя предлогами «от» и «до», каждый из которых употребляется с существительным в родительном падеже. Эти многозначные предлоги в ряде случаев составляют единую грамматическую пару, создающую синтаксическую схему «от чего-то до чего-то». Предлог «от» с существительным в родительном падеже в соединении с предлогом «до» и с другим существительным в родительном падеже используется при определении пространственных или временных границ чего-л.: «от Москвы до Петербурга 600 км», «От рассвета до заката с ней служить и с ней дружить...», или же в переносном смысле: «От любви до ненависти один шаг». При обозначении границ какой-либо части пространства, протяжения, рас- 
стояния и т. п. «от» обозначает первый предел, границу, а «до», соответственно, - другой предел, другую границу: «От Урала до Дуная, / До большой реки, / Колыхаясь и сверкая / Движутся полки...» (ЛЕРмонтов 1957: 71). Содержащееся, которое находится между границами, имеет векторную направленность: от одного к другому; поэтому иногда в данной конструкции вместо предлога «до» употребляется предлог «к»: «от Москвы к Петербургу», «от рассвета к закату». То же и в поэзии: «От славных вод Балтийских края / К востоку путь свой простирая...» (Ломоносов 1965: 143). В сознании, воспринимающем высказывание с конструкцией «от чего-то до чего-то», происходит движение мысли от одного предмета к другому, причем «от» указывает на источник, начало, исходный пункт движения и направление чего-л., в то время как «до» показывает пространственный или временной предел, конец. Этим значение предложной пары «от... до» отличается от значения предлога «между», указывающего на то, что находится или совершается внутри обозначенных границ, но который делает каждую из ограниченных точек равноправной и равноценной. Здесь направленность отсутствует; динамики нет. Это первое, что бы хотелось подчеркнуть в семантике данного предложного единства.

Второе: казалось бы, что предлоги «от» и «до» должны ограничивать собою линию - «от Москвы до Петербурга». При обозначении длины расстояния это действительно так. Но когда с помощью данных предлогов дается не величина расстояния, а какая-либо иная характеристика содержащегося между двумя точками, то имеется в виду не направленная прямая (вектор), но все пространство (площадь). Так, например, если в выражении «от Москвы до Петербурга 600 км» имеется в виду прямая линия определенной длины, то в выражении «от Москвы до Петербурга тянутся смешанные леса»-характеристика площади, ее наполненность: леса тянутся не только вдоль линии железной дороги, но по всему пространству - от широты Москвы до широты Петербурга. Отсюда и в «формуле протяжения» объектом характеристики становится не столько расстояние, сколько площадь, поверхность, причем, поверхность, разворачивающаяся в определенном направлении.

Для русского самосознания величина занимаемой Россией территории часто служила предметом гордости (удовлетворяя своего рода национальные амбиции) - самая обширная страна (равно как и некоторые другие исключительные по тем или иным показателям географические явления российской территории: самое большое озеро на планете - Каспийское, самое глубокое озеро - Байкал, самая длинная река Европы - Волга). Случаи проявления этой гордости, чувства удовлетворенности российским пространством, территорией, бесчисленны. Приведем только несколько примеров из поэзии Ломоносова. В Хотинской оде 1739 г.: «Чрез нас предел наш стал широк / На север, запад и восток. / На юге Анна торжествует...» (Ломоносов 1965: 66); в 10 оде 1747 г.: «Пространная твоя держава / О как тебе благодарит! / Воззри на горы превысоки, / Воззри в поля твои широки...» (Ломоносов 1965: 124-125); в 14 оде 1754 г. в обращении к Богу: «Воззри к нам с высоты свя- 
тыя, / Воззри, коль широка Россия, / Которой дал ты власть и цвет. / От всех полей и рек широких, / От всех морей и гор высоких / К тебе взывали девять лет» (Ломоносов 1965: 154-155); а в 19 оде 1762 г.: «Обширность наших стран измерьте» (Ломоносов 1965: 189). То же во многих текстах советского времени - от знаменитой «Песни о Родине» на слова В. Лебедева-Кумача («Широка страна моя родная, / Много в ней лесов, полей и рек») до менее известного «Марша юных туристов»: «У нас дорог немало, / Широк простор / От синего Байкала / До Крымских гор».

Даже территория Древней Руси, во много раз меньшая, чем территория Российской империи, была достаточно обширной и, очевидно, вызывала чувство гордости, судя по частому акценту, который делался на этой теме в памятниках древнерусской письменности. Понятия ширь, безбрежность, безграничность неизменно употребляются в них в положительном контексте. «Восторг перед просторами, - пишет по этому поводу Д. С. Лихачев, - присутствует уже и в древней русской литературе - в летописи, в «Слове о полку Игореве», в «Слове о погибели Русской земли», в «Житии» Александра Невского - да почти в каждом произведении древнейшего периода XI-XIII вв. [...] Издавна русская культура считала простор и большие расстояния величайшим этическим и эстетическим благом» (ЛихАчев 1983: 53). Такое отношение к пространству настолько привычно для российского мироощущения, что порою представляется самоочевидным и неоспоримым, хотя можно указать на примеры совершенно противоположного отношения к территории страны - гордости малым, довольства малыми площадями и расстояниями: «Наша маленькая родина».

«Империальная формула», обычно оперирующая географическими ориентирами - горами, реками, морями, а иногда - населенными пунктами, находящимися на границах государства, представляет собой один из примеров выражения такой гордости обширностью, пространностью территории. Пумпянский, говоря о поэтическом новаторстве Ломоносова в использовании риторической фигуры «от чего-то до чего-то» и отмечая, что русские поэтысиллабики XVII в. ее не знали, не отметил, однако, что она встречается уже в памятниках древнерусской письменности. Так, в «Слове о погибели Русской земли», созданном в середине XIII столетия и связанном с монголо-татарским нашествием, представлен один из ярчайших и вполне оригинальных примеров использования этой конструкции. Он широко известен, но все же позволим себе процитировать его полностью для того, чтобы показать, как она строится в данном случае: «Отсель до угоръ и до ляховъ, до чаховъ, от чаховъ до ятвязи и от ятвязи до литвы, до немець, от нъ мець до корђлы, от корђлы до Устьюга, гдъ тамо бяху тоимици погании, и за Дышючимъ моремъ; от моря до болгаръ, от болгарь до буртасъ, от буртасъ до чермисъ, от чермис до моръдви, - то все покорено было богомъ крестияньскому языку, поганскыя страны, великому князю Всеволоду, отцю его Юрью, князю кыевьскому; дъду его Володимеру и Манамаху, которымъ то половоци дети своя полошаху в колыбели» (Слово 1981: 131). 
Здесь конструкция «от чего-то до чего-то» представлена девятикратным повтором, и внутри периодов предлог «до» с существительным употребляется порою до трех раз: «до угоръ и до ляховъ, до чаховъ...». Как она строится в «Слове о погибели Русской земли»? В качестве ориентиров называются территории соседних государств и племен: Венгрии (угров), Чехии (чахов), Польши (ляхов), литовских племен (ятвягов), народов, господствовавших в Прибалтике (видимо, немцев или шведов), корелов, волжских болгар, языческих племен, живших по берегам Верхней и Нижней Тоймы (притоков Северной Двины) (тоймицы поганы), мордовских племен (буртасы), марийцев (черемисы) и мордвы. Кроме того, обозначен один пограничный город (Великий Устюг) и Белое море или Северный Ледовитый океан («Дышущее море»).

Автору «Слова о погибели Русской земли» необходимо было подчеркнуть громадность, обширность территории, бывшей во владении князя Всеволода Большого Гнезда, его отца Юрия Долгорукого и деда Владимира Мономаха. При Всеволоде, незадолго до того, как бо́льшая часть Русской земли была завоевана монголо-татарами, существенно возросло могущество Владимиро-Суздальского княжества. С помощью многократного повтора конструкции «от... до» и при обильном использовании названий соседних земель автор достигает художественного эффекта, акцентируя тем самым величину пространства, занимаемого русскими княжествами. Он ведет свое перечисление в порядке следования граничащих с Русью народов и тем самым вся ее площадь с запада, севера и востока представляется охваченной соседними территориями. В двух случаях называются территории, не имевшие в XIII веке границ с Русскими княжествами (Чехии и волжских болгар), один раз нарушена последовательность перечисления, когда болгары называются ранее «тоймиц поганых»; но, несмотря на эти нарушения, тенденция к географической последовательности прослеживается достаточно четко. Здесь дано не пересечение площади, как может показаться, а именно незамкнутая кривая, идущая по рубежу. И только с юга, со стороны степи, граница оказывается разомкнутой, однако названные далее половцы, не включенные в конструкцию «от... до», замыкают круг. Вопрос о том, откуда, из какой географической точки, начинает автор «Слова» свое перечисление, в каком пункте он находится (или воображает себя) в момент написания данного произведения, до сих пор остается дискуссионным. Но где бы ни находилось это «отселе», ясно, что автор мысленно проводит прямую от себя до первого западного соседа и от него следует по периметру на север, а далее - на восток и юг. Обильность пограничий «работает» в данном случае на создание впечатления обширности территории русской земли: чем больше соседей, тем больше территория.

Л. И. Сазонова, оспаривая утверждение Пумпянского, показала, что «империальная формула» органично вписалась и в поэзию русского барокко. «Стихотворные тексты XVII в., введенные в научный оборот в последние десятилетия, - пишет исследовательница, - позволяют установить существо- 
вание „империальной формулы“ и у русских силлабиков» (САзоновА 1991: 157). В ее работе приведен ряд примеров использования конструкции «от... до» русскими поэтами второй половины XVII в.: «От востока свет веры приемлеши / ею же тайны церкви обемлеши / Даже до запад просветишся ею» (Сильвестр Медведев); «Криле простер, обемлет всего мира конца / Север, юг, от восток аж до запад солнца» (Иоанн Максимович) (САзоновА 1991: 158).

Но все же особую популярность «империальная формула» приобрела в поэзии классицизма, и, прежде всего - в жанре оды. В этом отношении Пумпянский совершенно справедливо называет Ломоносова зачинателем этой традиции: все послеломоносовские ее употребления непосредственно или же опосредовано восходят именно к нему. Впрочем, и Сумароков, скорее всего, независимо от Ломоносова, уже в 1743 г., как показывает Пумпянский, опирается на нее, говоря о том, что императрица «в единый миг своей рукой / Объяла все свои границы»: «Взгляни в концы своей державы, / Царица полунощных стран, / Весь Север чтит твои уставы / До мест, что кончит океан, / До края областей безвестных» (Пумпянский 1983: 159). Пумпянский писал, что у Ломоносова конструкция «от... до» является прямым заимствованием «из общего фонда европейской оды, для которой она давно уже была привычным элементом то придворного комплиментирования, то национальнопатриотической гордости»; разница состоит в том, что западноевропейская поэтическая традиция использовала ее не к протяжению территории, а к «пределам славы». Но как только немецким поэтам, которые служили в Петербурге при императорском дворе, «пришлось писать оды на русскую тему, формула сразу ярко ожила» (Пумпянский 1983: 23). Так, Юнкер в оде 1742 г. пишет: «Таково желание - от Балтийского до Японского моря, / От Каспийского моря до того [места], где белый медведь перебирается через ледяные горы на краю земли» [перевод Пумпянского]. «Наконец-то, - продолжает ученый, - немецкая ода нашла страну с географией, благоприятствующей территориальному комплиментированию!» (Пумпянский 1983: 24).

Мы приведем ряд примеров использования конструкции «от чего-то до чего-то» из стихотворных текстов Ломоносова: «От теплых уж брегов Азийских / Вселенной часть до вод Балтийских / В объятьи вашем вся лежит» (Ломоносов 1965: 72); здесь: «вселенной часть» - это Россия; «в объятьи вашем» - т. е. в объятье императрицы Анны Иоанновны. «От славных вод Балтийских края / К востоку путь свой простирая, / Являешь полдень над Москвой» (Ломоносов 1965: 143) - говорится о Елизавете Петровне, которая сияет «в концы державы своея». «Желая то, гласят брега Балтийских вод, / До толь, где кажет свой яппонцам солнца всход; / И от Каспийских волн до гор, где мраз насильный, / Где мал народ, больших зверей стада обильны» (Ломоносов 1965: 451). «С Дунайских и до Камских вод / Вливает свет Христов в народ...» (Ломоносов 1965: 173) - говорится о Владимире Первосвятителе. «От тихих всточных вод до берегов Балтийских, / От непроходных льдов до теплых стран Каспийских / В одеждах много коль и в лицах перемен!» (Ломоносов 1965: 230). 
Ломоносов мысленно простирает взгляд по территории России и с запада на восток, и с востока на запад, и с севера на юг, и с юга на север. Для ограничения Российских рубежей он пользуется терминами физической географии и топонимами, опираясь на естественные границы, разрывы, водоразделы, которые являются одновременно и политическими разделами между Россией и соседними государствами. Поэзия Ломоносова не только географична, но картографична: создается впечатление, что он пишет оды, видя перед собой карту России и оперируя ею в своих поэтических построениях. Отсюда обилие топонимов и географической лексики. Географическая конкретность обозреваемой им площади проявляется в многократном использовании названий морей (Каспийское, Белое, Балтийское, Понтийское), рек (Волга, Дон, Днепр, Двина, Обь, Лена, Енисей, Дунай, Висла) и гор (Кавказские, Рифейские, Таврские, Молдавские). О подобных «гео-этнических панорамах» писал В. Н. Топоров: они «узреваются как бы сверху и издалека единым взглядом, создающим единое и целостное представление-картину» (ТопоРов 1997: 35). Ломоносов характеризует указанные им пограничья по большей части образно: он не только называет рубежи империи, но дает микро-климатические пейзажи: не просто Дунай, но «устье быстрых струй Дунайских», не просто север, но «горы, где мраз насильный» или же «непроходные льды», не просто Каспий, но «теплые страны Каспийские» и т. п. Эти микро-характеристики географических ориентиров впоследствии были подхвачены Пушкиным, который дополнил их историческими аллюзиями и перифразами: «Или от Перми до Тавриды, / От финских хладных скал до пламенной Колхиды, / От потрясенного Кремля / До стен недвижного Китая, / Стальной щетиною сверкая, / Не встанет русская земля?» (Пушкин 1948: 270). ${ }^{1}$

Территория Российской империи на севере и востоке имела водные границы, а на западе и юге - преимущественно речные и горные. На карте Россия, вытянутая с запада на восток, представлялась Ломоносову как бы покоящейся на своих западных и южных границах, и этот образ органично соединялся с представлением о женской ее природе: Россия - женщина, возлюбленная или же мать, как в «Разговоре с Анакреоном». Картографический ее образ (очертания ее границ), видимо, сыграл определенную роль в создании одической топики России, особенно в тех случаях, где дается феминизированный ее образ - когда она изображается в виде женщины (что, конечно же, усиливалось и подкреплялось тем, что Россией правили императрицы), ${ }^{2}$ как, например, в 11 оде 1748 г. Ломоносов восклицает: «Коль ныне радостна Россия! / Она, коснувшись облаков, / Конца не зрит своей державы; / Гремящей

\footnotetext{
${ }^{1}$ Приведу несколько других примеров «империальной» формулы из произведений Пушкина, который использовал ее не менее охотно, чем Ломоносов: «От Рущука до старой Смирны, / От Трапезунда до Тульчи, / Скликая псов на праздник жирный, / Толпой ходили палачи»; «И делу своему Владыка сам дивился. / Се благо, думал он, и взор его носился / От Тибровых валов до Вислы и Невы, / От сарскосельских лип до башен Гибралтара»; «От западных морей до самых врат восточных / Не многие умы от благ прямых и прочных / Зло могут отличить».

${ }^{2}$ О роли женского мифа в русской культуре см. HUBBS 1988.

Studia Slavica Hung. 60, 2015
} 
насыщенна славы, / Покоится среди лугов» (Ломоносов 1965: 132). Обратим внимание на живописность изображения Ломоносовым территории России и ее границ: он любуется ими, ему доставляют эстетическое наслаждение очертания занимаемой ею площади - это ложе, на котором Россия «покоится». Они представляются Ломоносову совершенно органичными. В той же 11 оде он рисует Россию, возлежащую на ложе: «В полях, исполненных плодами, / Где Волга, Днепр, Нева и Дон, / Своими чистыми струями / Шумя, стадам наводит сон, / Седит и ноги простирает / На степь, где Хину отделяет / Пространная стена от нас; / Веселый взор свой обращает / И вкруг довольства исчисляет, / Возлегши лактем на Кавказ» (Ломоносов 1965: 132). Здесь Россия изображена сидящей на европейской своей территории («где Волга, Днепр, Нева и Дон»), ее ноги протянуты («ноги простирает») через Сибирь до великой китайской стены («туда, где Хину отделяет пространная стена от нас»), а локтем она опирается о Кавказ. По существу - это картина скорее возлежащей, нежели сидящей России: изголовьем ей служат поднимающиеся наверх, к северу, западные континентальные границы, притом что северные, разомкнутые, являют собою открытое пространство, небо.

У Хераскова тоже есть образ России-женщины, но он представлен в экспрессивной форме, поскольку те же самые реки и ее территория оказались в чужом владении: «Россия, прежнюю утратив красоту / И видя вкруг себя раздоры, пустоту, / Везде уныние, болезнь в груди столицы, [...] / В чужом владении Двину, Днепр, Волгу, Дон... / Возносит к небесам заплаканные очи, / Возносит рамена к небесному отцу, / Колена преклонив, прибегла ко творцу; / Открыла грудь свою, грудь томну, изъязвленну, / Рукою показав Москву окровавленну, / Другою - вкруг нее слиянно море зла; / Взрыдала, и рещи ни слова не могла» (ХЕРАсков 1972: 275). В этом отрывке из поэмы «Россиада» Россия изображена перед завоеванием Иваном Грозным Казани. Несмотря на то, что и здесь называются топонимы, картографический образ страны отсутствует; представлен только вид тяжело больной и страдающей женщины - с заплаканными глазами, с изъязвленной томной грудью, извергающей рыдания и пр. У Ломоносова в 8 оде 1746 г. есть похожий, хотя и менее развернутый образ: «Взирая... / На сильну власть чужой руки, / Россия ревностно вздыхала / И сердцем всякий раз взывала / К тебе, защитнице своей» (Ломоносов 1965: 110-111) («защитница» здесь: Елизавета Петровна). ${ }^{3}$

Со временем занимаемая Россией территория начала восприниматься не только как органичная, но и как совершенно естественная, законная и закономерная. В таком отношении весьма показательна передовая заметка Ф. Б. Булгарина в новогоднем номере «Северной пчелы» за 1840 г., где используется та же самая формула: «Отечество наше раздвинуло свои пределы и разлеглось от Тарнео и Лапонии до крайнего гирла Дуная, и от подножия

\footnotetext{
${ }^{3}$ В другой связи на то же самое есть намек у Тютчева в эпиграмме на гр. П. А. Шувалова, назначенного в 1866 г. шефом жандармов и начальником Третьего отделения: «Над Россией распростертой / Встал внезапною грозой / Петр по имени четвертый, / Аракчеев же второй» (Тютчев 1966: 186).
} 
Карпат до Арарата, от восточного берега Черного моря, к которому примыкает Кавказ. Теперь Россия в своих естественных пределах, недосягаемых и ненарушимых, после попыток Карла ХІІ и Наполеона» (БулгАРин 1840: 1). Здесь Булгарин подводит итоги российской экспансии от начала XIX в. до 1840 г., и названные им ориентиры соответствуют результатам завоеваний последних сорока лет: 1809 г. - присоединение Финляндии (Лапландия); 1812 г. - присоединение Бессарабии (гирло Дуная); 1815 г. - присоединение территорий Польши (подножие Карпат), 1810-1829 гг. - присоединение побережья Черного моря (восточный берег Черного моря); и наконец, 1828 г. присоединение Армении (Арарат). Называя российские пределы «естественными», Булгарин, видимо, имеет в виду как их обусловленность природными (естественными) водо- и горноразделами, так и их нормальность, так сказать, политическую обоснованность. Аналогичным представляется нам и выражение А. А. Кизеветтера в статье «Империя XVIII в.», (помещенной в томе «Россия» энциклопедического словаря Брокгауза и Эфрона), который, говоря о «работе над округлением границ», отметил, что к началу XVIII в. «территориальный рост русского государства еще не достиг своих естественных пределов» (КизЕВеттеР 1991: 469). Подобными же «естественными» климатическими и ландшафтными категориями оперирует и Н. С. Трубецкой в своей евразийской работе 1925 г. «Наследие Чингисхана», очерчивая территорию России «как основного ядра монгольской монархии» «почти от Тихого океана до устьев Дуная» (ТруБЕцкой 1955: 213).

Для Булгарина, равно как и для Ломоносова, границы России представляются естественными, закономерными и законными. По крайней мере, тут нет претензий на дальнейшее их расширение. Нероссийские географические ориентиры появляются у Ломоносова только тогда, когда речь заходит не о величине территории империи, но о широте распространения российской славы. В таких случаях «империальная формула» превращается в «формулу протяжения» российской военной мощи и славы: «От устья быстрых струй Дунайских / До самых узких мест Ахайских / Меча Российска виден блеск» (Ломоносов 1965: 75), - пишет он по поводу завоевания русскими войсками турецкой крепости Хотин в 1739 г.; «От Иберов до вод Курильских, / От вечных льдов до токов Нильских, / По всем народам и странам / Ваш слух приятный протекает...» (Ломоносов 1965: 108), - говорит он Елизавете Петровне о пределах распространения ее славы. С тем же самым мы встречаемся как в произведениях значительно более раннего периода, см. «Житие Александра Невского»: «И нача слыти имя его по всъм странамъ, и до моря Хонужьскаго, и до горъ Араратьскых, и об ону страну моря Варяжьскаго, и до великаго Риму» (Житие 1981: 434), так и в текстах гораздо более позднего времени, как, например, в знаменитой песне «Марш Красной Армии», написанной в 1920 г. (авторство текста приписывается П. Г. Горштейну): «От тайги до Британских морей / Красная Армия всех сильней».

Когда речь заходит о единении «братьев-славян», конструкция «от чегото до чего-то» начинает включать в себя территории и топонимы территорий 
славянских народов, как, например, у Тютчева: «О, какими вдруг лучами / Озарились все края! / Обличилась перед нами / Вся славянская земля! / Горы, степи и поморья / День чудесный осиял, // От Невы до Черногорья / От Карпатов за Урал. // Рассветает над Варшавой, / Киев очи отворил, / И с Москвой золотоглавой / Вышеград заговорил!» (Тютчев 1966: 114).

Иногда «империальная формула», выражая мечту об осуществлении экспансии России за ее (на каждый данный момент) существующие границы, использует те географические ориентиры, которые в состав России никогда не входили. Именно с этим мы встречаемся в стихотворении Тютчева «Русская география»: «От Нила до Невы, от Эльбы до Китая, / От Волги по Евфрат, от Ганга до Дуная... / Вот царство русское... и не прейдет вовек, / Как то предвидел Дух и Даниил предрек» (Тютчев 1966: 118). Здесь конструкция «от... до/по» употреблена четырехкратно, а протяженность России представлена с юга на север («От Нила до Невы») с упоминанием Нила, который никогда России не принадлежал, хотя мечты об этом были и даже строились соответствующие планы (вспомним хотя бы прожекты Павла I - см. КоролЕВ 1997: 129); с запада на Дальний Восток («от Эльбы до Китая»), с упоминанием Эльбы, которая также никогда не была «русской» рекой; с запада на Ближний Восток - от Волги по Евфрат; и наконец «от Ганга до Дуная» (где высказывается давняя мечта об экспансии России на Индию). Для Тютчева, таким образом, «естественность» границ России, якобы завещанных еще библейским пророчеством (Дан. II, 44), распространяется далеко за пределы реальных ее рубежей, существующих на конец 1840-х гг., когда было написано это стихотворение. То же и в другом тексте Тютчева 1853 или 1854 г. «Спиритическое предсказание», где отмеченные им в «Русской географии» границы названы «завещанными»: «Дни настают борьбы и торжества, / Достигнет Русь завещанных границ, / И будет старая Москва / Новейшею из трех ее столиц» (Тютчев 1966: 136). Здесь в поэтической форме представлена геополитическая утопия, нашедшая выражение в определенных концепциях и оказавшаяся достаточно живучей. Она восходит к формуле «Москва - Третий Рим» и встречается уже в XVIII в. То же самое «произвольное конструирование идеала» (КоРолЕв 1997: 127) характерно и для ряда поэтов XVIII в., как, например, для В. И. Майкова (по мнению которого, «нынешние юноши», т. е. юноши 1770-х гг., «в твое владычество [Екатерины II - Е. Д.] богатство принесут, / Индию съединят с Российскою страною / И Хинуво твое подданство приведут...» (МАйков 1966: 293), и для Г. Р. Державина, который в стихотворении «Мой истукан» пишет: «Доступим мира мы средины, / С Гангеса злато соберем; / Гордыню усмирим Китая, / Как кедр наш корень утверждая» (ДЕРЖАВИН 1972: 601).

Еще гораздо более смелая геополитическая утопия, выраженная «империальной формулой», дана в стихотворении «Лирическое отступление», написанном в 1940 году автором знаменитой «Бригантины» Павлом Коганом, который приписывает будущему Советскому Союзу территорию едва ли не всего «Евро-Азиатского» континента: «Но мы еще дойдем до Ганга, / Но мы 
еще умрем в боях, / Чтоб от Японии до Англии / Сияла Родина моя» (КогАН 1965: 309; см. об этом Костюхин 1955: 25). На этом фоне притязания и мечты В. В. Жириновского представляются не столь уж оригинальными. Излагая собственную геополитическую концепцию, названную им «формулой Жириновского», лидер либерально-демократической партии, ограничивая «правовое, экономическое, политическое и финансовое пространство» желанной для него России, охотно пользуется «имперской» формулой»: «... каждый должен быть, - пишет он, - под защитой закона, под сенью закона, который действует во времени и пространстве на всей этой территории - от Кабула до Стамбула, от Южного побережья Индийского океана до побережья Северного Ледовитого океана» (Жириновский 1966: 125). ${ }^{4}$

Избитость «империальной формулы», многократно использовавшейся самыми разными поэтами XVIII в., архаистами, Пушкиным, Лермонтовым, Вяземским (который, впрочем, с раздражением писал в 1831 г.: «Мне так уж надоели эти географические фанфаронады наши: От Перми до Тавриды и проч.» - ВязЕмский 1992: 155) и другими известными и малоизвестными авторами, становится очевидной уже в первой половине XIX века. Именно эта конструкция обыгрывается в шутливом коллективном «Каноне в честь М. И. Глинки», написанном в 1836 г. по поводу первого представления оперы «Жизнь за царя» («За прекрасную новинку / Славить будет глас молвы / Нашего Орфея Глинку / От Неглинной до Невы»), где традиционно в качестве ориентиров указываются не города (Москва и Петербург), а метонимически реки: Неглинка и Нева. Эта же формула использована С. А. Соболевским в дружеской эпиграмме (по выражению М. И. Гиллельсона - «задиристом дружеском экспромте») (ГиллЕльсон 1988: 13) на братьев Полевых: «Нет подлее до Алтая / П[олево]го Николая / И глупее нет до Понта / П[олево]го Ксенофонта» (Соболевский 1988: 307). ${ }^{5}$ Когда в 1854 г. Н. А. Добролюбов высмеивает тему прославления российских пространств, уже к тому времени превратившуюся в пошлую банальщину, он опять же вспоминает «империальную формулу» или «формулу протяжения России»: «Нет во вселенной такого оратора, / Чтобы прославить твое протяжение: / С полюса тянешься ты до экватора, / Смертных умы приводя в изумление» (ДоБролюБов 1960: 405). Манипуляция географическими ориентирами становится предметом осмеяния и в пародии Е. П. Ростопчиной, датированной 1856 г.: «Примеру

\footnotetext{
${ }^{4}$ Приведем другие примеры использования В. В. Жириновским «формулы протяжения»: «Просто большая страна. И она действительно большая - от Балтики до Владивостока. Так сложилось» (ЖиРиновский 1966: 124); «Когда-то Красная конница шла на Варшаву и был такой призыв: «Вперед до Ла-Манша», «Даешь Варшава - Берлин - Ла-Манш» (ЖиРиновский 1966: 122); «Это не только решение внутренней проблемы России и успокоения народов от Кабула до Стамбула» (Жириновский 1966: 35).

${ }^{5}$ См. развернутый вариант данной эпиграммы: «От Каспийского / До Балтийского, / До большого, до Черного понта / Нет подлее, / Нет сквернее / Полевого Ксенофонта. / От Кавказского / До Уральского, / До большого хребта до Алтая / Нет сквернее / Нет подлее / Полевого Николая» (СоБолЕвСкий 1988: 13), где «формула протяжения славы» (точнее - бесславия) опирается на привычные поэтические ориентиры.
}

Studia Slavica Hung. 60, 2015 
благому послушны, / Пусть наши и ваши поля / Сойдутся, - в день встречи радушной / Взыграет родная земля!.. / Ты, Волга, целуйся с Дунаем!.. / Урал, ты Карпат обнимай!.. / Пляшите, как браться, край с краем, / И всё, что не мы, - пропадай!..» (РостопчинА 1960: 400-401). Здесь пляшущие, целующиеся и обнимающиеся друг с другом реки и горы, конечно же, восходят к ломоносовским олицетворениям: «Брега Невы руками плещут...» и т. д. Появление шутливых текстов, обыгрываний, пародий всегда является свидетельством избитости, заштампованности темы, приема, жанра, конструкции. K середине XIX века, действительно, казалось, что «формула протяжения» изжила себя.

Однако, революционная поэзия последней трети XIX столетия, которая в процессе выработки своей поэтики нередко усваивала уже отработанные, шаблонные, приемы, вдруг дает этой формуле новую жизнь. Конструкция «от чего-то до чего-то» оказывается в высшей мере подходящей для выражения всеобщности охватившего Россию протеста против старого мира, как, например, в песне П. Лаврова 1875 г. «Отречемся от старого мира»: «Встанем, братья, повсюду зараз! / От Днепра и до Белого моря, / И Поволжье, и Дальний Кавказ! / На воров, на собак - на богатых!» (ЛАвРов 1988: 216). Ср. также песни на слова В. Г. Тан-Богораза, написанные в конце XIX начале XX в.: «От края до края родимой страны / Друг другу несем / Мы ласточки свежей зеленой весны, / Идущей за нами вослед» (Песни 1988: 290$292)$; «От Камы до желтого Прута, / Как буйного моря волна, / Растет беспощадная смута, / Кипит роковая война [...] / Объяты багровым разгулом / И запад и дальний восток» (ТАН-БоГОРАЗ 1988: 294-295).

В советское время «формула протяжения» оказалась весьма удобной для выражения всеобщего оптимизма и нашла себе место во многих советских (и особенно - в пионерских) песнях, где она эксплуатировалась на все лады. Когда надо было сказать, что песня звенит по всей стране, говорилось: «Звени наша песня, / От края до края, - / Песня советской земли!» (МАСлЕнников 1959: 158); когда надо было сказать, что школьные звонки звенят по всей стране, говорилось: «звенят разноголосые звонки / От Дальнего Востока до Карпат» (МАслЕников 1959: 26); когда надо было сказать, что дороги идут по всей стране, говорилось: «От морей до гор высоких / Посреди родных широт / Все бегут, бегут дороги / И зовут они вперед...» (ПришЕЛЕЦ 1952: 132) и т. д.

«Формула протяжения» и в этот период опиралась главным образом на пограничья, рубежи, и, следовательно, пересечение территории страны давалось в ней «от края и до края». Однако, встречаются примеры и «радиального» ее строения, где площадь Советского Союза разворачивается не от границы к границе, а по радиусу, причем центром, «сердцем Родины», всегда называется Москва: либо от окружности к центру, как, например, в песне «Да здравствует наша держава» на слова А. Ишлова: «От дальней советской границы / До башен старинных Кремля / Растут города и станицы / Цветут золотые поля» (Ишлов 1982: 61); либо - чаще - от центра к окружности, как в знаменитой «Песне о Родине» из кинофильма 1935 г. «Цирк», где дополни- 
тельно охват территории происходит также с юга на север: «От Москвы до самых до окраин, / С южных гор до северных морей / Человек проходит как хозяин / Необъятной Родины своей». В «Корреспондентской застольной», написанной в 1943 году К. Симоновым для спектакля по его пьесе «Жди меня», «формула протяжения» указывает направление от Москвы к западу, что оправдывается движением войск советской армии: «От Москвы до Бреста / Нет такого места, / Где бы не скитались мы в пыли, / С лейкой и блокнотом, / А то и с пулеметом / Сквозь огонь и стужу мы прошли».

В советской патриотической песне происходит вырождение «формулы протяжения». Во-первых, в ней все чаще называется не топоним, а просто край, граница, как, например в знаменитой «Кантате о Сталине» на слова М. Инюшкина: «От края до края, по горным вершинам, / Где вольный орел совершает полет, / О Сталине мудром, родном и любимом / Прекрасную песню слагает народ»; или как в заключительном хоре из оперы «Тихий Дон» «От края и до края, / От моря и до моря...» (Душенко 1977: 114); ср. также с песней на слова А. Прокофьева «Город славы боевой»: «Ты лети от края и до края, / Мчись над родиной труда, / Наша песня молодая, / Не смолкая никогда» (ПрокофьЕв 1945: 7). ${ }^{6}$ Во-вторых, в тех случаях, когда пограничные топонимы все же называются, они оказываются лишенными характерной для ломоносовской поэтики микро-характеристики, как, например, в «Путевой пионерской» на слова С. Михалкова: «От Белого моря до Черного, до всех других морей, / От дальнего, восточного прицела батарей - / Везут, везут курьерские И взрослых и ребят, / И песни пионерские Поет в пути отряд» (МихАлков 1952: 46) (здесь, кстати, указано еще и дополнительное направление - в противоположную сторону: туда, куда нацелены батареи). И наконец, в-третьих, конструкция «от... до», как правило, утрачивает в стихе свой ритмообразующий смысл. Если в ломоносовском четырехстопном ямбе первый стих начинался с «от», а следующий с «до», то в советской песне вся конструкция вмещается в одну строку, как, например, в «Марше молодых строителей» на стихи Ю. Визбора: «От Карпатских долин до Таймыра / Мы идем по дорогам крутым. / Коммунизм - это молодость мира, / И его возводить молодым!» (ПахмутовА 1963: 39).

Формула «от... до» со значением - повсюду, по всему пространству русской земли использовалась уже поэтами XVIII в., как, например, Державиным в «Памятнике»: «Слух про́йдет обо мне от Белых вод до Черных, / Где Волга, Дон, Нева, с Рифея льет Урал; / Всяк будет помнить то в народах неисчетных, / Как из безвестности я тем известен стал...» (ДЕРжАВин 1985: 175). Со временем эта формула из риторической конструкции превращается во фразеологизм, факт языка, становясь синонимом выражения «по всей стране», как, например, в высказывании Н. С. Лескова о книгоиздателе М. О. Вольфе: «Его армия разбросана от Якутска до Варшавы, от Риги до Ташкента...»

${ }^{6}$ Ср. также стихотворение А. Суркова: «Мы пройдем от края и до края / По Советской солнечной стране...».

Studia Slavica Hung. 60, 2015 
(ЛиБРович 1916: 6); в публицистической прозе в этом значении она встречается постоянно: «От Керчи до Ижмо-Печерского уезда всюду вступило в свои права...» (ОльшевеЦ 1926: 4); «...объездил страну от Калининграда до Камчатки...» (ШТАКЕЛЬБУРГ 1996: 21); СССР простирается «от Минска до Владивостока» (С. 1926: 2) и т. д. В 1990-е гг. эта конструкция была подхвачена рекламой: «От Парижа до Находки / Omsa - лучшие колготки» и пр.

Подводя итог сказанному, отметим, что наша работа ограничивается только русским материалом, однако сомневаться в интернациональности «формулы протяжения» не приходится, хотя «империальный» характер она приобретает далеко не всегда. В своем кратком, географически не конкретизированном варианте эта конструкция представлена уже в «Псалтыри»: «Он будет обладать от моря до моря и от реки до концов земли» $($ Пс. 71,8$) ;^{7}$ широко известно ходовое латинское выражение «A mari usque ad mare», написанное, кстати, в качестве девиза на гербе Канады (БАБичеВ-Боровский 1988: $60)$. Ее вариации использовались римской поэтической традицией, прежде всего - Горацием, который, как пишет М. Л. Гаспаров, «часто уносится воображением к самым дальним границам своего круга земель...» (ГАСПАРОВ 1970: 16); см., например, в его «Эподе І»: «Хоть по Кавказу дикому, / Хоть до пределов самых крайних запада / С тобой пойду бесстрашно я» (ГорАций 1970: 217). Она охотно использовалась в польской поэзии - сначала в качестве интенсификации славы, а позже, после падения Польши - как формула ее былого величия. Претензия на ту же «великую Польшу от моря до моря» прослеживается, например, в «Песне армии генерала Юзефа Довбор-Мусницкого» (1918 г. [?]): «Od źródel Niemna po szlak morza, / Po Odry brzegi, szczyty Tatr / I hen, po stepi Zaporoźa, / Niech wieść na skrzydłach niesie wiatr!» (ROMANOWSKI 1990: 565). ${ }^{8}$ Мы встретились с примером применения «формулы протяжения» по отношению к территории Белоруссии: она содержится в речи Якуба Коласа «К мести, братья славяне», произнесенной на Третьем Всеславянском митинге в Москве 9 мая 1943 г.: «Пусть вся наша земля - от Беловежской пущи до Приднепровья, от Бреста до Гомеля, от Белостока до озерной Витебщины - запылает под ногами врага!» (МихАлков 1998: 209), где указанные топонимы ограничивают рубежи Белоруссии. ${ }^{9}$ Применяется она и в американской поэтической традиции. Так, например, в известной

\footnotetext{
${ }^{7}$ Ср. использование этого выражения Пушкиным в «Борисе Годунове»: «Да славится он от моря и до моря».

${ }^{8}$ См. также песню на слова Эдварда Слонского (1918 г.): «I ciebie, ziemio piastowa, / płużyła bagnetów stal / od śnieżnych Karpat i Lwowa / do szarych Bałtyku fal» (RoMANOwSKI 1990: 674); в текстах Яна Лехоня при использовании «формулы протяжения» заметно проступает романтическая ирония, приводящая к пародированию «великодержавных» иллюзий: «Сzyli to będzie w Sofii, czy też w Waszyngtonie, / Od egipskich piramid do śniegów Tobolska / Na tysiączne się wiorsy rozsiadła nam Polska...» (ROMANOWSKI 1990: 669); см. также: «Od Wilna do Poznania pojedzie się szosą, / Na prawo będzie Polska i Polska na lewo...» (RomANOwski 1990: 667).

${ }^{9} \mathrm{Cp}$. также явно инспирированную «Казачью думу о Сталине»: «От высокого Казбека / До Каспийских берегов / Льется жизнь тобой согрета / Жизнь советских казаков» (ИСАКОВ 1952: 309).
} 
песне «America the Beautiful», созданной на слова Катарины Бейтс (1893 г.), есть яркий пример «формулы протяжения Америки»: «This land is your land, this land is my land / From California to the New York Island. / From the Redwood Forest to the Gulf Stream waters? / This land was made for you and me». He coмневаемся, что подобного рода примеры могут быть умножены. Конечно, в каждой культуре «формула протяжения» имеет свою историю и свой смысл, что видно уже из последнего примера, поэтому вопрос о том, в какой мере исследуемая нами конструкция является универсальной, какой смысл она имеет в «имперских» и в «неимперских» культурах, остается пока открытым.

Второй нерешенный нами вопрос, касающийся «формулы протяжения», связан с распадом Советского Союза. Если с уверенностью можно сказать, что поэзия советского периода широко и на все лады эксплуатировала ее, особенно в патриотической песне, то новые границы России, до сих пор (в той или иной мере) травмирующие сознание россиянина, могут повлиять таким образом, что данная конструкция либо прекратит свое существование, либо же будет использоваться в новых геополитических утопиях. Территория России даже в современных ее масштабах все еще очень обширна. Однако, отсутствие пограничных опор на естественных рубежах (горах, реках, морях) и непривычность географических очертаний, приводят к тому, что картографический ее образ оказывается как бы лишенным прежней органичности, которая столь радовала глаз русского человека на протяжении трех веков. Как пишет Й. ван Баак, в России «потерялось привычное сочетание пространственных ориентиров и привычной многовековой имперской „обширности“» (БААК 1995: 13). Эта утрата привычных очертаний пространственных ориентиров и привычных очертаний границ может привести как к утрате, так и к возрождению одной из популярных риторических формул, имеющих в русской литературе долгую историю, о которой и шла речь в настоящей работе.

\section{Литература}

БААК 1995 = БААК ВАН Й. О границах русской культуры. Русская литература 1995/3: $12-20$.

БАБИЧЕВ-БОРОВСКИЙ 1988 = БАБИЧЕВ Н. Т., БОРОВСКИЙ Я. М. Словарь латинских крылатых слов. Москва, 1988.

БУЛГАРИн $1840=$ БулГАРИн Ф. В. [Вступительная статья.] Северная пчела 1840, № 1. 2 января.

ВязЕмСКИй 1992 = ВязЕмСКий П. Записные книжки. Москва, 1992.

ГАСПАРОВ $1970=$ ГАСПАРОВ М. Л. ПоэзИЯ Горация. В кн.: ГОРАциЙ: Odbl. Эnoды. Caтиры. Послания. Москва, 1970. 5-38.

ГилЛЕЛЬСОН 1988 = ГиллЕЛьСОН М. И. Русская эпиграмма. В кн.: Русская эпиграмма (XVIII - начала XX века). Ленинград, 1988. 5-44.

ГОРАциЙ 1970 = ГОРАций: Оды. Эподы. Сатиры. Послания. Москва, 1970.

ДЕРЖАВИН 1972 = ДЕРЖАВИН Г. Р. Мой истукан. В кн.: Русская поэзия XVIII века. Москва, 1972. 596-602.

ДЕРЖАВИН 1985 = ДЕРЖАВИН Г. Р. Сочинения. Москва, 1985.

Studia Slavica Hung. 60, 2015 
ДоБРолюБов 1960 = ДоБРолюБов Н. А. Родина. В кн.: Русская стихотворная пародия (XVIII - начало ХІХ в.). Ленинград, 1960. 405-406.

ДушенКО 1977 = ДушЕнко К. В. Словарь современных циттат. 4300 ходячих ичитат и выражений ХХ века, их источники, авторы, датировка. Москва, 1977.

ЖиРиновский 1966 = ЖиРиновский В. В. Последний бросок на юг. Москва, 1996.

Житие 1981 = Житие Александра Невского. В кн.: Памятники литературы Древней Руси. ХІІІ век. Москва, 1981. 426-439.

ИСАКОВ 1952 = ИСАКОВ А. Казачья дума о Сталине. В кн.: Песни для детей. Москва, Ленинград, 1952. 308-309.

Ишлов 1982 = Ишлов А. Да здравствует наша держава. В кн.: Взвейтесь кострами... Пионерские песни. Москва, 1982. 61.

КИзеветтеР 1991 = КизеветтеР А. А. Империя XVIII в. В кн.: Россия. Энциклопедический словарь. Ленинград, 1991. 466-478.

КОГАН 1965 = КОГАН П. Лирическое отступление. В кн.: Советские поэты, павшие на Великой Отечественной войне. Москва-Ленинград, 1965. 308-309.

КОРОЛЕВ 1997 = КОРОЛЕВ С. А. Бесконечное пространство. Гео- и соичографические образы власти в России. Москва, 1997.

Костюхин 1955 = Костюхин Е. А. Русские в Средней Азии. Мифы и реальность. Русская литература 1995/3: 20-29.

ЛАВРОВ 1988 = ЛАВРОВ П. «Отречемся от старого мира». В кн.: Песни русских поэтов в 2 томах. Т. 2. Ленинград, 1988. 215-216.

ЛЕРмонтов 1957 = ЛЕРмонтов М. Ю. Собрание сочинений в 4 томах. Т. 1. Москва, 1957.

ЛиБРОВич 1916 = ЛиБРОвич С. Ф. На книжном посту. Петроград-Москва, 1916.

ЛИХАЧЕВ 1983 = ЛИХАЧЕВ Д. С. Земля родная. Москва, 1983.

Ломоносов 1965 = Ломоносов М. В. Избранные произведения. Москва-Ленинград, 1965.

МАЙКОВ 1966 = МАЙКОВ В. И. Избранные произведения. Москва-Ленинград, 1966.

МАСЛЕНИКОВ 1959 = МАСЛЕНИКОВ В. Звенят звонки. В кн.: Антология советской детской песни. Вып. 2. Москва, 1959. 26.

МихАлков 1952 = МихАЛков С. В. Путевая пионерская. В кн.: Песни для детей. Москва-Ленинград, 1952. 46.

МихАЛКОВ 1998 = МиХАЛКОВ С. От и до... Москва, 1998.

ОЛЬШЕВЕЦ 1926 = ОЛЬШЕВЕЦ М. ПровинциальНЫе заметКИ. Известия 1926. № 160. 15 июля.

ПАХмУтовА 1963 = ПАХмУтовА А. Песни тревожной молодости. Сборник песен с сопровождением баяна. Москва, 1963.

ПРИШЕЛЕЦ 1952 = ПРИшЕЛЕЦ А. И. Наш край. В кн.: Песни для детей. Москва-Ленинград, 1952. 132.

ПРОКОФЬЕВ 1945 = ПРОКОФьЕВ А. Город славы боевой. В кн.: Песни ленинградских пионеров. Ленинград, Москва, 1945. 7.

Пумпянский 1983 = ПумПянский Л. В. Ломоносов и немецкая школа разума. В кн.: Русская литература XVIII - начала XX века в общественно-культурном контекcme. (XVIII век. Сб. 14.) Ленинград, 1983. 3-44.

Пушкин 1948 = Пушкин А. С. Полное собрание сочинений. Т. 3. Кн. 1. Ленинград, 1948.

РостоПчина 1960 = Ростопчина Е. П. Стихотворение Элеикина. В кн.: Русская стихотворная пародия (XVIII - начало XX в.). Ленинград, 1960. 400-401. 
С. 1926 = С. Ставка на невежество. Вечерняя Москва, 1926. 11 октября.

САЗОНОВА 1991 = САЗОНОВА Л. И. Поэзия русского барокко (вторая половина ХVII начало ХVIII в.). Москва, 1991.

Слово 1981 = Слово о погибели русской земли. В кн.: Памятники литературы Древней Руси. ХІІІ век. Москва, 1981. 130-131.

СоБоЛЕВСКиЙ 1988 = СоБОЛЕВСКий С. А. [На Н. А. и Кс. А. Полевых]. «От Каспийского...». В кн.: Русская эпиграмма (XVIII - начало ХХ века). Ленинград, 1988. 307.

ТАН-БОГОРАЗ 1988 = ТАН-БОГОРАЗ В. Г. Цусима. В кн.: Песни русских поэтов в 2 томax. Т. 2. Ленинград, 1988. 293-295.

ТопоРОв 1997 = ТопоРов В. Н. Гео-этнические панорамы в аспекте связей истории и культуры (к происхождению и функциям). В кн.: Культура и история. Славянский мир. Москва, 1997. 23-61.

ТРУБЕЦКОЙ 1955 = ТРУБЕЦКОЙ Н. С. История. Культура. Язык. Москва, 1955.

ТюТчев 1966 = ТюТчев Ф. И. Лирика в двух томах. Т. 2. Москва, 1966.

ХеРАсков 1972 = ХеРАсков М. М. Россиада. В кн.: Русская поэзия XVIII века. Москва, 1972. 270-283.

ШТАКЕЛЬБУРГ 1996 = ШТАКЕЛЬБУРГ Л. ПасЫнКИ ПОЗДНеЙ имПерии. ФрагментЫ ненаписанного романа. Звезда 1996/5: 15-73.

Hubbs 1988 = Hubbs J. Mother Russia. The Feminine Myth in Russian Culture. Bloomington and Indianapolis: Indiana University Press, 1988.

RomANOwski 1990 = Romanowski Andrzej (oprac.): Rozkwitały pqki białych róż. Wierszei pieśni z lat 1908-1918 o Polsce, o wojnie i o żotnierzach. Warszawa, 1990. 